\title{
First evidence of bryophyte diaspores in the plumage of transequatorial migrant birds.
}

Correlations between transequatorial migratory bird routes and bipolar biogeographic disjunctions in bryophytes suggest that disjunctions between northern and southern high latitude regions may result from bird-mediated dispersal; supporting evidence is, however, exclusively circumstantial. Birds disperse plant units (diaspores) internally via ingestion (endozoochory) or externally by the attachment of diaspores to the body (ectozoochory). Endozoochory is known to be the primary means of bird-mediated dispersal for seeds and invertebrates at local, regional, and continental scales. Data supporting the role of birdmediated endozoochory or ectozoochory in the long distance dispersal of bryophytes remain sparse, however, despite the large number of bryophytes displaying bipolar disjunctions. To determine if transequatorial migrant shorebirds may play a role in the ectozoochory of bryophyte diaspores, we developed a method for screening feathers of wild birds. We provide the first evidence of microscopic bryophyte diaspores, as well as those from non-bryophyte lineages, embedded in the plumage of long distance transequatorial migrant birds captured in their arctic breeding grounds. The number of diaspores recovered per feather suggests that entire migratory populations may be departing their northern breeding grounds laden with potentially viable plant parts and that they could thereby play significant roles in bipolar range expansions of lineages previously ignored in the migrant bird dispersal literature. 
1 Title: First evidence of bryophyte diaspores in the plumage of transequatorial migrant birds.

2 Authors: Lily R. Lewis ${ }^{1}$, Emily Behling ${ }^{1}$, Hannah Gousse ${ }^{1}$, Emily Qian ${ }^{1}$, Chris S. Elphick ${ }^{1}$, Jean-

3 François Lamarre ${ }^{2}$, Joël Bêty ${ }^{2}$, Joe Liebezeit ${ }^{3}$, Ricardo Rozzi $^{4}$, Bernard Goffinet ${ }^{1}$

4 Affiliations: ${ }^{1}$ Department of Ecology and Evolutionary Biology, University of Connecticut,

5 Storrs, CT 06269, USA; ${ }^{2}$ Centre d'Études Nordiques et Département de Biologie, Université du

6 Québec à Rimouski, Québec, Canada, G5L 3A1; ${ }^{3}$ Audubon Society of Portland, OR 97210,

7 USA; ${ }^{4}$ Omora Ethnobotanical Park, Puerto Williams, Antarctic Province, Chile; Department of

8 Philosophy, University of North Texas, Denton TX 76201, USA.

9 Correspondence: Lily R. Lewis. Ecology and Evolutionary Biology, University of Connecticut,

1075 N Eagleville Road, U-3043, Storrs, CT 06269 USA. Email: Lily.Lewis@uconn.edu

1 Dlilyrlewis@gmail.com, emily.behling@uconn.edu, hgousse@gmail.com, emily.qian@uconn.edu, chris.elphick@uconn.edu,

2 jflamarre@gmail.com, joel_bety@uqar.ca, jliebezeit@audubonportland.org, ricardo.rozzi@unt.edu, bernard.goffinet@uconn.edu 


\section{Introduction}

12 Climate, geological processes, and long-distance dispersal shape global species

13 distributions. Although wind is the primary vector for long-distance dispersal (LDD) of

14 microscopic diaspores in the northern (Wilkinson et al., 2012) and southern (Muñoz et al., 2004)

15 hemispheres, it is an unlikely candidate for explaining bipolar disjunctions (i.e., transequatorial

16 distributions between high latitude areas), which characterize many sporic plants, including at

17 least 60 species of moss (Ochyra, 1992; Ochyra \& Buck, 2003; Ochyra, Smith \& Bednarek-

18 Ochyra, 2008), 17 liverwort species (Schuster, 1983; Bednarek-Ochyra et al., 2000), and 160

19 lichen species (Øvstedal \& Lewis Smith, 2001). Bipolar disjunctions at the species or

20 infrageneric levels largely originated in the Miocene through the Pleistocene (Wen \& Ickert-

21 Bond, 2009; Popp, Mirré \& Brochmann, 2011; Fernández-Mendoza \& Printzen, 2013) and thus

22 correspond with the continued presence of the Intertropical Convergence Zone (Hyeong et al.,

23 2005), which produces a barrier to wind dispersal across low latitudes. This time frame predates

24 human activities, which in modern times have greatly expanded dispersal opportunities

25 (Wilkinson, 2010). Inferences based on molecular data have largely supported direct LDD across

26 the tropics as the process shaping bipolar disjunctions in plants and lichens (Wirtz, Printzen \&

27 Lumbsch, 2008; Wen \& Ickert-Bond, 2009; Kreier et al., 2010; Popp, Mirré \& Brochmann, 2011;

28 Piñeiro et al., 2012), with only a few examples supporting ancient vicariance (Mao et al., 2012)

29 or stepwise migration across the tropics (Fernández-Mendoza \& Printzen, 2013). Bird migration

30 routes between boreal and austral regions provide a direct link between antipodal populations,

31 and hence migratory birds are routinely invoked as the dispersal vectors that account for bipolar

32 disjunctions (Du Rietz, 1940; Wen \& Ickert-Bond, 2009; Popp, Mirré \& Brochmann, 2011).

33 Evidence of birds dispersing sporic plant or lichen units (i.e., diaspores), as well as those of other

34 lineages, across the tropics, however, is exclusively circumstantial. 
Birds may disperse diaspores internally (endozoochory) or externally (ectozoochory;

36 Ridley, 1930; Carlquist, 1974). The feasibility of avian mediated endozoochory in the LDD of

37 aquatic invertebrates and seed plants is well supported by diaspore retention times in captive

38 birds and the survival of ingested diaspores (Proctor, 1968; Figuerola \& Green, 2002) as well as

39 the recovery of viable seeds from the dung of wild birds (Bruun, Lundgren \& Philipp, 2008).

40 Based on experimentally derived retention times and viability estimates paired with migratory

41 movement data, modeling of potential dispersal distances supports intercontinental-scale

42 movement of aquatic organisms and seeds (Viana et al., 2013). The effects of avian ingestion on

43 the spores of the liverwort Riella was explored by Proctor (1961) who demonstrated that viable

44 spores could be recovered from the dung of domesticated mallard ducks (Anas platyrhynchos)

45 after approximately 30 minutes. Spores of slime molds have been recovered from the dung of

46 migratory songbirds (Suthers, 1985). Furthermore, bryophyte spores and vegetative diaspores

47 have been shown to withstand ingestion by slugs (Arion vulgaris, A. rufus, and Limax

48 cinereoniger; Boch et al., 2013), or by the spectacled flying fox (Pteropus conspicillatus; Parsons

49 et al., 2007), respectively. Studies on seed plants have shown that the effects of internal passage

50 vary according to bird species and seed (Traveset, Riera \& Mas, 2001), but in general, diaspore

51 viability decreases with increasing exposure to a bird's digestive tract (van Leeuwen et al., 2012).

52 Alternatively, ectozoochory requires that (1) diaspores become attached to the exterior of

53 a bird prior to migration, and (2) remain on the bird over the course of the journey (Figuerola \&

54 Green 2002). Comparisons of endozoochory and ectozoochory of aquatic invertebrates and seed

55 plants suggest a secondary role of ectozoochory in terms of number and diversity of diaspores

56 dispersed (Brochet et al., 2010; Sánchez et al., 2012; Costa et al., 2013). Several studies,

57 however, suggest that ectozoochory may provide an important means of dispersal for fungi or

58 sporic plants. Viable fungal spores were recovered from the feathers of wild birds up to 45 days

59 after inoculation (Warner \& French, 1970) and diaspores of lichen-forming fungi can become 
60

61

62

63

64

65

66

67

68

69

70

71

72

73

74

75

76

77

78

79

80

81

82

83

84

attached to the feet of albatross (Bailey \& James, 1979). Screening of the coats and hooves of roe

deer (Capreolus capreolus), wild boar (Sus scrofa) (Heinken et al., 2001) and domesticated sheep

(Pauliuk, Müller \& Heinken, 2011) showed that mosses, most notably pleurocarpous mosses, are

commonly carried by mammals, despite lacking any specialized means of adhering to them

(Sorensen, 1986). Although birds are known to actively transport bryophytes locally for use as nesting material (Osorio-Zuñiga, Fontúrbel \& Håkan 2014), evidence for avian ectozoochory playing a role in the regional or global dispersal of bryophytes is lacking. To test this hypothesis we sought to assess whether the first condition for ectozoochory of bryophytes would be met, namely do potential vectors between high latitude ecosystems harbor bryophyte diaspores.

To evaluate the first condition for ectozoochory by transequatorial migrant birds, we developed a method for microscopically screening feathers for diaspores. We present the results from the screening of 23 individual birds, representing eight transequatorial long-distance migrant species in the order Charadriiformes (shorebirds) captured in their arctic breeding grounds. We provide empirical evidence demonstrating that the first condition for ectozoochorous LDD is met, and with a frequency that suggests that birds are active carriers of diaspores and thus may play a critical role in shaping global species distributions.

\section{Methods}

Feather samples were collected from transequatorial migrant birds in their breeding ranges at a site along the Ikpikpuk River, U.S.A. (approximate location: $70.55343^{\circ} \mathrm{N}$, $154.69750^{\circ} \mathrm{W}$; United States Department of the Interior, permit \# 23566) and Bylot Island, Nunavut Territory, Canada (approximate locations: $73.15623^{\circ} \mathrm{N}, 79.97065^{\circ} \mathrm{W}$; and $72.89216^{\circ} \mathrm{N}$, 79.90510 W; Comité de protection des animaux de 1'Université du Québec à Rimouski, permit \# CPA-42-10-77 - R1) (Fig. 1) between late May and July of 2008 through 2013 by members of the Arctic Shorebird Demographic Network. Target bird species were selected based on migration paths connecting the Northern and Southern Hemispheres, having breeding and wintering ranges 
85 in habitats where bryophytes are abundant, and all represent members of the order

86 Charadriiformes. Feather sampling times correspond with the availability of mature bryophyte

87 spores, and preceded the commencement of fall migration. Individual birds were captured using

88 bow nets positioned on nests. When triggered, the bow nets formed a dome over the nest so birds

89 were not immobilized or pressed against the ground, thus lowering the risk that diaspores were

90 picked up due to extraordinary circumstances. Birds were held by grasping the back with clean

91 hands or using nitrile gloves. Feathers were sampled from the base of the breastbone, to minimize

92 invasiveness of feather removal, and based on our prediction that the ventral surface of birds is

93 most likely to make contact with mature bryophyte sporophytes, which are typically erect, or

94 vegetative parts of bryophyte mats. Three to six contour and undercoat feathers were collected

95 using tweezers from each bird and immediately placed into a clean paper envelope. If prebasic

96 molt had begun, older-generation feathers were selected. Following collection, feathers were

97 stored in sealed paper envelopes at room temperature. Contour and undercoat feathers collected

98 from a single individual on the same date were pooled for screening. Feathers from 23 individual

99 birds, representing 8 species, American golden-plover (Pluvialis dominica; $\mathrm{n}=11$ individuals),

100 red phalarope (Phalaropus fulicarius; $\mathrm{n}=3$ ), red-necked phalarope (Phalaropus lobatus; $\mathrm{n}=2$ ),

101 ruddy turnstone (Arenaria interpres; $\mathrm{n}=1$ ), dunlin (Calidris alpina; $\mathrm{n}=1$ ), Baird's sandpiper

102 (Calidris bairdii; $\mathrm{n}=1$ ), white-rumped sandpiper (Calidris fuscicollis; $\mathrm{n}=1$ ), and semipalmated

103 sandpiper (Calidris pusilla; $\mathrm{n}=3$ ) were screened (Table 1).

104 All screening was performed in a laminar flow hood in which the surface of the work area

105 and all materials were sterilized with $10 \%$ bleach, $70 \%$ ethanol and 15 minutes of ultraviolet

106 light exposure. The laminar flow hood was located in a laboratory where bryophytes are not

107 handled. Feathers were placed in a sterile $1.5 \mathrm{~mL}$ centrifuge tube with $350 \mu \mathrm{L}$ of autoclaved

108 distilled water, and vortexed for $5 \mathrm{~min}$ at 2,500 rpm to dislodge any particulate matter attached to

109 the feather. The sample was then centrifuged for $5 \mathrm{~min}$ at $14,000 \mathrm{~g}$ to collect the particulate 
110

matter in the base of the microcentrifuge tube. The feather was removed from the tube and placed

111 in a second sterile $1.5 \mathrm{~mL}$ microcentrifuge tube for drying. The wash water was then re-

112 centrifuged for $3 \mathrm{~min}$ in case the pellet was disturbed when the feather was removed from the

113 tube.

114 Three hundred $\mu \mathrm{L}$ of supernatant were pipetted off and discarded following the second

115 centrifuging to reduce the sample size for efficient screening. The tube with the remaining $50 \mu \mathrm{L}$

116 of the wash water was vortexed to redistribute the pellet, and the solution divided into two $25 \mu \mathrm{L}-$

117 samples for microscopic examination. Samples were screened at 40X magnification. The

118 presence of any putative diaspores was recorded and photographed with a Nikon Coolpix E995

119 camera.

\section{Results \& Discussion}

121

We recovered 23 structures representing bryophytes (mosses and liverworts),

cyanobacteria, algae and fungi from the small down and contour breast feathers of two

123

semipalmated sandpipers, two red phalaropes, and three American golden-plovers; Table 1; Fig 1;

124 Fig 2). Two of the recovered structures are moss leaf fragments. The first is composed of

125 dimorphic cells, with relatively thin chlorophyllose cells alternating with wide hyaline cells,

126 characteristic of Sphagnum leaves (Goffinet, Buck \& Shaw, 2009; Fig. 1A). The second has

127 smooth elongate cells, most likely representing a moss from the class Bryopsida, potentially

128 belonging to the family Bryaceae s. lat. or to the the pleurocarpous mosses (superorder

129 Hypnanae; Goffinet, Buck \& Shaw, 2009; Fig. 1C). The third bryophyte structure is a liverwort

130 elater, an elongated cell with two helical thickenings (Crandall-Stotler, Stotler \& Long, 2009;

131 Fig. 1B). Elaters are dead, hygroscopic structures in the capsule that aid in the dispersal of the

132 spores. The presence of an elater in the plumage highlights that even rare structures, available

133 during limited periods of the year may be picked-up by birds. The recovery of two vegetative 
134 diaspores suggests that unspecialized diaspores, which are available consistently throughout the

135 year, may play an important role in ectozoochory of bryophytes.

136 The behavior of these transequatorial migrant birds in their northern breeding grounds

137 likely promotes their inadvertent acquisition of diaspores. American golden-plovers,

138 semipalmated sandpipers, and red phalaropes all breed in coastal tundra (Tracy, Schamel \& Dale,

139 2002; Hicklin \& Gratto-Trevor, 2010; Johnson \& Connors, 2010), where bryophytes are

140 common. Shallow nests are constructed by scraping depressions into the ground with breast, feet

141 and beaks, and are commonly lined with plant materials (Tracy, Schamel \& Dale, 2002; Hicklin

142 \& Gratto-Trevor, 2010; Johnson \& Connors, 2010).Timing of molt and migratory behavior will

143 affect the likelihood of attached diaspores being dispersed across the birds' migratory range. Molt

144 in American golden-plovers and semipalmated sandpipers takes place primarily after concluding

145 southward migration, but may occasionally commence before they leave the Arctic (Pyle, 2008;

146 Hicklin \& Gratto-Trevor, 2010; Johnson \& Connors, 2010). Red phalaropes replace most body

147 feathers prior to, and flight feathers after, southward migration (Tracy, Schamel \& Dale, 2002;

148 Pyle, 2008). American golden-plovers and semipalmated sandpipers make only terrestrial

149 stopovers throughout their migration to South America (Hicklin \& Gratto-Trevor, 2010; Johnson

150 \& Connors, 2010), while red phalaropes travel largely over the ocean and spend the non-breeding

151 period offshore (Tracy, Schamel \& Dale, 2002). The individuals screened for this study were

152 sampled between June and July (with one exception being a ruddy turnstone sampled on May

$\left.15331^{\text {st }}\right)$. Fall migrations in the species found to be vectors commence as early as July for

154 semipalmated sandpipers and red phalaropes, and August for American golden-plovers (Tracy,

155 Schamel \& Dale, 2002; Hicklin \& Gratto-Trevor, 2010; Johnson \& Connors, 2010), which

156 overlaps with the production of spores by many arctic bryophyte species. Vegetative fragments

157 are constantly available and do not require any temporal correlations between vectors and

158 diaspores. The post-migratory molt and terrestrial destinations of American golden-plovers and 
159

160

161

162

163

164

165

166

167

168

169

170

171

172

173

174

175

176

177

178

179

180

181

182

183

semipalmated sandpipers are compatible with the requirements for dispersal across the equator

and subsequent establishment of diaspores. The majority of migratory shorebirds with non-

breeding grounds in the Southern Hemisphere provide similar opportunities for diaspore

dispersal, with the molt typically occurring on the southern non-breeding grounds (Pyle, 2008).

Prior evidence of ectozoochory by birds has shown that this process plays a role in the

dispersal of aquatic invertebrates (Dundee, Phillips \& Newsom, 1967; Green \& Figuerola, 2005;

Sánchez et al., 2012), seed plants (Brochet et al., 2010; Costa et al., 2013), and fungi (Warner \&

French, 1970). Sporic plants commonly exhibit broad intercontinental disjunctions, even across

disjunctions that lack wind connectivity. Despite this situation, little work has been done to

investigate the possibility of long distance ectozoochory of sporic plants by birds. Our

observations provide unequivocal evidence of bryophyte, fungal and protist diaspores, embedded

within the plumage of transequatorial migrant birds, demonstrating that the first condition for

bird-mediated ectozoochory is met. Furthermore, our study suggests that vegetative fragments

may be significant dispersal units for ectozoochory of bryophytes, supported more broadly by the screening of non-avian vectors (Heinken et al., 2001; Pauliuk, Müller \& Heinken, 2011), relative

to anemochory whereby spores may be the primary dispersal units. Experimental studies

comparing the ability of spores and vegetative fragments to attach and be carried by animal

vectors will be necessary to explore this hypothesis further.

The potential of diaspores to establish new populations depends on their sustained

viability over the course of dispersal. In bryophytes, resistance of spores to the extreme

conditions associated with LDD by wind is a determinant of a given species' potential for wind

mediated range expansions, with continental endemics displaying greater vulnerability during

transport than transoceanic disjunct species (van Zanten, 1978). The conditions experienced by

diaspores trapped in the plumage of a bird are plausibly less severe than those associated with

high atmospheric wind dispersal. Bryophytes are well known for their physiological drought 
184 tolerance and the totipotency of their vegetative tissues, which can develop mature plants even

185 after severe grinding (Shaw, 1986), rapid passage through a mammalian digestive tract (Parsons 186 et al., 2007) and even after being frozen under a glacier for 400 years (La Farge, Williams \&

187 England, 2013). Future work will explicitly address the second condition for successful

188 ectozoochory by employing culturing techniques to assess viability of recovered diaspores and

189 DNA barcoding for diaspore identification. Based on the general literature supporting the

190 resilience of vegetative bryophyte diaspores, however, resistance to dispersal conditions is

191 unlikely a strong selective force governing the effectiveness of bird-mediated ectozoochory and

192 associated range expansions (Sánchez, et al., 2012).

193 Establishment of a new population is a stochastic event following any mode of dispersal,

194 and may pose the greatest challenge toward range expansions. Considering that 23 diaspores

195 were recovered from seven out of 23 birds sampled, the frequency with which birds may

196 externally transport such structures over time may be sufficiently high to explain bipolar

197 distributions. Extrapolated to entire migratory populations, which range in size in North America 198 from 500,000 individuals for American golden-plovers to 2,260,000 individuals for semipalmated

199 sandpipers (Andres et al., 2012), hundreds of thousands of diaspores may be transported annually

200 across the Equator, dramatically increasing the probability of successful dispersal, establishment

201 and thereby range extension.

202 Acknowledgements: Louise Lewis provided access to a laminar flow hood, Richard Lanctot

203 helped in the submission of this project to the Arctic Shorebird Demographic Network, the Arctic

204 Shorebird Demographic Network provided support and collaboration, Margaret Rubega and

205 Matthew Chmielewski provided advice on project development, Susan Hochgraf assisted with

206 preliminary protocol testing, Rafael Medina provided laboratory assistance, and Cameron Rutt 
207

208

209

210

211

212

213

214

215

216

217

218

219

220

221

222

223

224

225

226

227

228

contributed bird photos. Andy Green, Casper van Leeuwen, and one anonymous reviewer provided valuable feedback on the initial submission of this work.

\section{Literature Cited}

Andres BA, Smith PA, Morrison RIG, Gratto-Trevor CL, Brown SC, Friis CA. 2012. Population estimates of North American shorebirds, 2012. Wader Study Group Bulletin 119:178-194.

Bailey R, James P. 1979. Birds and the dispersal of lichen propagules. Lichenologist 11:105-106.

Bednarek-Ochyra H, Vana J, Ochyra R, Lewis Smith RI. 2000. The liverwort flora of Antarctica. Poland: W. Szafer Institute of Botany, Polish Academy of Sciences.

Boch S, Berlinger M, Fischer M, Knop E, Nentwig W, Türke M, Prati D. 2013. Fern and bryophyte endozoochory by slugs. Oecologia 172:817-822.

Brochet AL, Guillemain M, Fritz H, Gauthier-Clerc M, Green AJ. 2010. Plant dispersal by teal (Anas crecca) in the Camargue: duck guts are more important than their feet. Freshwater Biology 55:1262-1273.

Bruun HH, Lundgren R, Philipp M. 2008. Enhancement of local species richness in tundra by seed dispersal through guts of muskox and barnacle goose. Oecologia 155:101-110.

Carlquist S. 1974. Island biology. New York \& London: Columbia University Press.

Costa MJ, Ramos JA, da Silva LP, Timoteo S, Araújo PM, Felgueiras MS, Rosa A, Matos C, Encarnação P, Tenreiro PQ, Heleno RH. 2014. Endozoochory largely outweights epizoochory in migrating passerines. Journal of Avian Biology 45:59-64.

Crandall-Stotler B, Stotler RE, Long DG. 2009. Morphology and classification of the Marchantiophyta. In: Goffinet B \& Shaw AJ, ed, Bryophyte biology, 2nd ed. Cambridge: Cambridge University Press, 1-54. 
Du Rietz GE. 1940. Problems of bipolar plant distribution. Acta Phytogeographica Suecica

231 Dundee DS, Phillips PH, Newsom JD. 1967. Snails on migratory birds. Nautilus 80:89-91.

232 Fernández-Mendoza F, Printzen C. 2013. Pleistocene expansion of the bipolar lichen Cetraria 233 aculeata into the Southern hemisphere. Molecular Ecology, 22, 1961-83.

234 Figuerola J, Green AJ. 2002. Dispersal of aquatic organisms by waterbirds: a review of past 235 research and priorities for future studies. Freshwater Biology 47:483-494.

Goffinet B, Buck WR, Shaw AJ. 2009. Morphology and classification of Bryophyta. In: Goffinet B \& Shaw AJ, ed, Bryophyte biology, 2nd ed. Cambridge: Cambridge University Press, $55-138$

Green AJ, Figuerola J. 2005. Recent advances in the study of long-distance dispersal of aquatic invertebrates via birds. Diversity and Distributions 11:149-156.

Hicklin P, Gratto-Trevor CL. 2010. Semipalmated sandpiper (Calidris pusilla). In: Poole A ed, The Birds of North America Online. Ithaca: Cornell Lab of Ornithology.

Heinken T, Lees R, Raudnitschka D, Runge S. 2001. Epizoochorous dispersal of bryophyte stem fragments by roe deer (Capreolus capreolus) and wild boar (Sus scrofa). Journal of Bryology 23:293-300.

Hyeong K, Park S, Yoo CH, Kim K. 2005. Mineralogical and geochemical compositions of the eolian dust from the northeast equatorial Pacific and their implications on paleolocation of

Johnson OW, Connors PG. 2010. American Golden-Plover (Pluvialis dominica). In: Poole A ed, 250 The Birds of North America Online. Ithaca: Cornell Lab of Ornithology

251 Kreier HP, Feldberg K, Mahr F, Bombosch A, Schmidt AR, Zhu RL, von Konrat M, Shaw B, 252 Shaw AJ, Heinrichs J. 2010. Phylogeny of the leafy liverwort Ptilidium: Cryptic 
speciation and shared haplotypes between the Northern and Southern Hemispheres. Molecular Phylogenetics and Evolution 57:1260-1267.

255 La Farge C, Williams KH, England JH. 2013. Regeneration of Little Ice Age bryophytes emerging from a polar glacier with implications of totipotency in extreme environments. Proceedings of the National Academy of Sciences 110:9839-9844.

Mao K, Milne RI, Zhang L, Peng Y, Liu J, Thomas P, Mill RR, Renner SS. 2012. Distribution of living Cupressaceae reflects the breakup of Pangea. Proceedings of the National Academy of Sciences 109:7793-7798.

261 Muñoz J, Felicísimo AM, Cabezas F, Burgaz AR, Martínez I. 2004. Wind as a long-distance dispersal vehicle in the Southern Hemisphere. Science 304:1144-1147.

Ochyra R. 1992. Amblyodon dealbatus (Musci, Meesiaceae) - A bipolar disjunct. Fragmenta Floristica et Geobotanica 37:251-259.

Ochyra R, Smith L, Bednarek-Ochyra H. 2008. The illustrated moss flora of Antarctica. New York: Cambridge University Press.

Ochyra R, Buck WR. 2003. Arctoa fulvella, new to Tierra del Fuego, with notes on transAmerican bipolar bryogeography. Bryologist 106:532-538.

Osorio-Zuñiga F, Fontúrbel FE, Håkan R. 2014. Evidence of mutualistic synzoochory between cryptogams and hummingbirds. Oikos 123:553-558.

Øvstedal DO, Lewis Smith RI. 2001. Lichens of Antarctica and South Georgia: A guide to their identification and ecology. Studies in Polar Research. Cambridge: Cambridge University Press.

274 Parsons JG, Cairns A, Johnson CN, Robson SKA, Shilton LA, Westcot DA. 2007. Bryophyte 275 dispersal by flying foxes: a novel discovery. Oecologia 152:112-114. 
276 Pauliuk F, Muller J, Heinken T. 2011. Bryophyte dispersal by sheep on dry grassland. Nova Hedwigia 92:327-341.

278 Piñeiro R, Popp M, Hassel K, Listl D, Westergaard KB, Flatberg KI, Stenøien HK, Brochmann C. 279 2012. Circumarctic dispersal and long-distance colonization of South America: the moss 280 genus Cinclidium. Journal of Biogeography 39:2041-2051.

281 Popp M, Mirré V, Brochmann C. 2011. A single Mid-Pleistocene long-distance dispersal by a bird 282 can explain the extreme bipolar disjunction in crowberries (Empetrum). Proceedings of the National Academy of Sciences 108:6520-6525.

284 Proctor VW. 1961. Dispersal of Riella spores by waterfowl. Bryologist 64:58-61.

285 Proctor VW. 1968. Long-distance dispersal of seeds by retention in digestive tract of birds. 286 Science 160:321-322.

Pyle P. 2008. Identification guide to North American birds, part II. Point Reyes Station, CA: Slate Creek Press.

Ridgeley RS, Allnutt TF, Brooks T, NcNicol DK, Mehlman DW, Young BE, Zook JR, BirdLife International. 2012. Digital distribution maps of the birds of the Western Hemisphere, version 5.0. In BirdLife International \& NatureServe Bird species distribution maps of the world Version 2.0. Arlington, USA: BirdLife International, Cambridge, UK and NatureServe.

Ridley HN. 1930. The dispersal of plants throughout the world. Ashford, England: L. Reeve \& 295 Co. Ltd.

296 Sánchez MI, Hortas F, Figuerola J, Green AJ. 2012. Comparing the potential for dispersal via 297 waterbirds of a native and an invasive brine shrimp. Freshwater Biology 57:1896-1903.

298 Schuster RM. 1983. Chapter 10. Phytogeography of the Bryophyta. In Schuster RM, ed, New 299 manual of Bryology. Nichinan, Miyazaki, Japan: Hattori Botanical Laboratory. 
300 Shaw AJ. 1986. A new approach to the experimental propagation of bryophytes. Taxon 35:671$301 \quad 675$.

302 Sorensen AE. 1986. Seed dispersal by adhesion. Annual Review of Ecology and Systematics

$303 \quad 17: 443-463$.

304 Suthers HB. 1985. Ground-feeding migratory songbirds as cellular slime mold distribution

$305 \quad$ vectors. Oecologia 65:526-530.

306 Tracy DM, Schamel D, Dale J. 2002. Red Phalarope (Phalaropus fulicarius). In: Poole A, ed, The 307 birds of North America online. Ithaca: Cornell Lab of Ornithology.

308 Traveset A, Riera N, Mas RE. 2001. Passage through bird guts causes interspecific differences in 309 seed germination characteristics. Functional Ecology 15:669-675.

van Leeuwen CHA, van der Velde G, van Groenendael JM, Klaassen M. 2012. Gut travellers: internal dispersal of aquatic organisms by waterfowl. Journal of Biogeography 39:2031-2040.

Viana DS, Santamaria L, Michot TC, Figuerola J. 2013. Migratory strategies of waterbirds shape the continental-scale dispersal of aquatic organisms. Ecography 36:430-438.

van Zanten BO. 1978. Experimental studies on trans-oceanic long-range dispersal of moss spores in the Southern Hemisphere. Journal of the Hattori Botanical Laboratory 44:455-482.

317 Warner GM, French DW. 1970. Dissemination of fungi by migratory birds: survival and recovery of fungi from birds. Canadian Journal of Botany 48:907-910.

319 Wen J, Ickert-Bond SM. 2009. Evolution of the Madrean-Tethyan disjunctions and the North and 320 South American amphitropical disjunctions in plants. Journal of Systematics and Evolution 47:331-348.

322 Wilkinson DM. 2010. Have we underestimated the importance of humans in the biogeography of 323 free-living terrestrial microorganisms? Journal of Biogeography 37:393-397. 
324 Wilkinson DM, Koumoutsaris S, Mitchell EAD, Bey I. 2012. Modelling the effect of size on the 325 aerial dispersal of microorganisms. Journal of Biogeography 39:89-97.

326 Wirtz N, Printzen C, Lumbsch HT. 2008. The delimitation of Antarctic and bipolar species of

327 neuropogonoid Usnea (Ascomycota, Lecanorales): a cohesion approach of species

328 recognition for the Usnea perpusilla complex. Mycological research 112:472-484. 


\section{Table $\mathbf{1}_{\text {(on next page) }}$}

Feather screening results.

Bird species screened, total number of individuals (and feathers) screened, total number of vectors detected (individual bird carrying diaspores) per species, and individual vector identities (reported as location and date of sampling) and number of diaspores recovered per individual. Collection localities are shown in Fig. 1D - F. Recovered diaspores are shown in Fig. $1 \mathrm{~A}$ - C and Fig. $2 \mathrm{~A}$ - T. Thirteen diaspores were recovered from red phalarope Alaska22-June-2013. This bird showed no signs of sickness and did not exhibit any peculiar behaviors. Seven individuals representing three species were found to be vectors out of a total of 23 individuals representing 8 species screened. Small sample sizes likely account for the absence of diaspores in some species. [b] 


\begin{tabular}{|c|c|c|c|c|c|c|}
\hline Bird species & $\begin{array}{l}\text { Total individuals } \\
\text { screened (\# feathers) }\end{array}$ & $\begin{array}{l}\text { Total \# } \\
\text { Vectors }\end{array}$ & $\begin{array}{l}\text { Total \# } \\
\text { diaspores } \\
\text { recovered }\end{array}$ & Vector ID & $\begin{array}{l}\text { \# Diaspores } \\
\text { per vector }\end{array}$ & Figures(s) \\
\hline \multirow{3}{*}{ American golden-ployer } & $11(23)$ & 3 & 6 & Canada-30-June-2011 & 2 & $1 \mathrm{~B}, 2 \mathrm{P}$ \\
\hline & & & & Canada-7-July-2011 & 2 & $2 \mathrm{I}, \mathrm{N}$ \\
\hline & & & & Canada-13-July-2013 & 2 & $2 \mathrm{~B}, \mathrm{C}$ \\
\hline \multirow{2}{*}{ Semipalmated sandpiper } & $3(21)$ & 2 & 3 & Alaska-5-July-2013 & 2 & $2 \mathrm{D}, \mathrm{T}$ \\
\hline & & & & Alaska-6-July-2013 & 1 & $1 \mathrm{~A}$ \\
\hline \multirow[t]{2}{*}{ Red phalarope } & $3(14)$ & 2 & 14 & Alaska-22-June-2013 & $13^{\mathrm{a}}$ & $\begin{array}{l}1 \mathrm{C}, 2 \mathrm{~A}, \mathrm{~F}- \\
\mathrm{H}, \mathrm{J}-\mathrm{M}, \mathrm{O}, \\
\mathrm{Q}-\mathrm{S}\end{array}$ \\
\hline & & & & Alaska-29-June-2013 & 1 & $2 \mathrm{E}$ \\
\hline Red-necked phalarope & $2(8)$ & 0 & - & - & - & - \\
\hline Ruddy turnstone & $1(3)$ & 0 & - & - & - & - \\
\hline Dunlin & $1(2)$ & 0 & - & - & - & - \\
\hline Baird's sandpiper & $1(1)$ & 0 & - & - & - & - \\
\hline White-rumped sandpiper & $1(1)$ & 0 & - & - & - & - \\
\hline TOTAL & $23(73)$ & 7 & 23 & - & - & - \\
\hline
\end{tabular}

ㄹed phalarope Alaska-22-June-2013 harbored more diaspores than could be reliably counted, thus 13 representative diaspores were photo-documented. 


\section{Figure 1}

Bryophyte diaspores and their vectors.

Three bryophyte diaspores, (A) Sphagnum leaf fragment, (B) liverwort elater, and (C) Bryopsid moss leaf fragment recovered from (D) semipalmated sandpiper (Alaska-6-July2013), (E) American golden-plover (Canada-30-June-2011and (F) red phalarope (Alaska-22June-2013), respectively. $5 \mu \mathrm{m}$ horizontal scale bars are in the lower right corner of each diaspore image. Maps show Western Hemisphere breeding, migratory, and wintering distributions as well as rare sightings for each bird species (Ridgeley et al., 2012) . The migratory and wintering range for red phalaropes $(F)$ overlaps. Bird photo credits: Cameron Rutt.
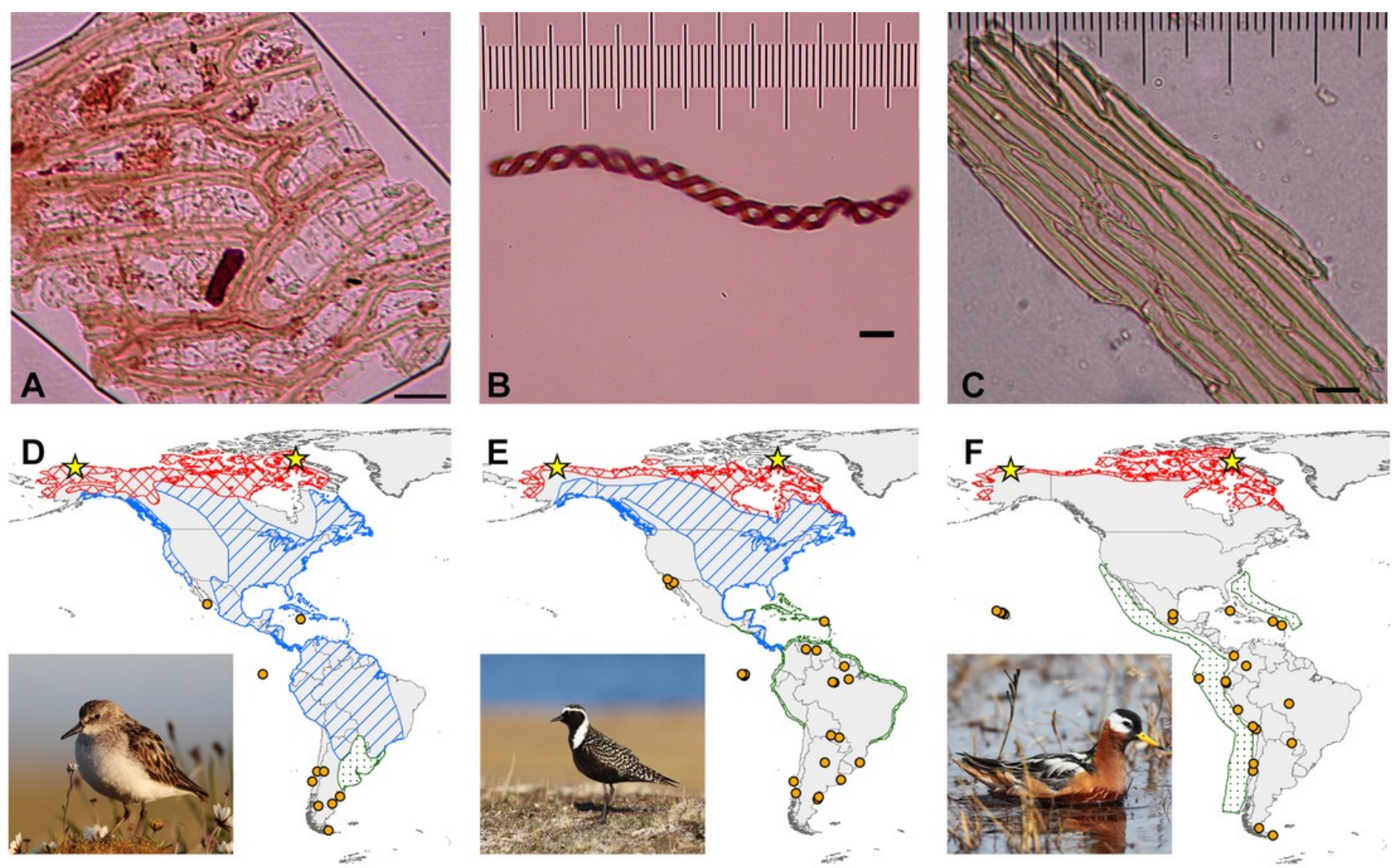

Key its $\begin{aligned} & \text { Sampling } \\ & \text { sites }\end{aligned} \quad \circ \begin{aligned} & \text { Rare } \\ & \text { sighting }\end{aligned}$ Breeding Wintering 1:250 000000 


\section{Figure 2}

Diaspores recovered from the feathers of 23 birds.

Twenty of a total of 23 putative diaspores recovered from breast feathers of migratory shorebirds in their breeding ranges. A-G, K, and $\mathrm{M}$ are believed to represent green algae or cyanobacteria; H \& I meiotic spores, with L representing an immature meiotic product; J, N, and $\mathrm{O}$ are multicellular plant fragments; P-T are fungal spores. $5 \mu \mathrm{m}$ horizontal scale bars are in the lower right corner of each image. Bryophyte diaspores are shown in Fig. 2 with their vectors. Vectors for each diaspore are listed in Table 1. [b] 


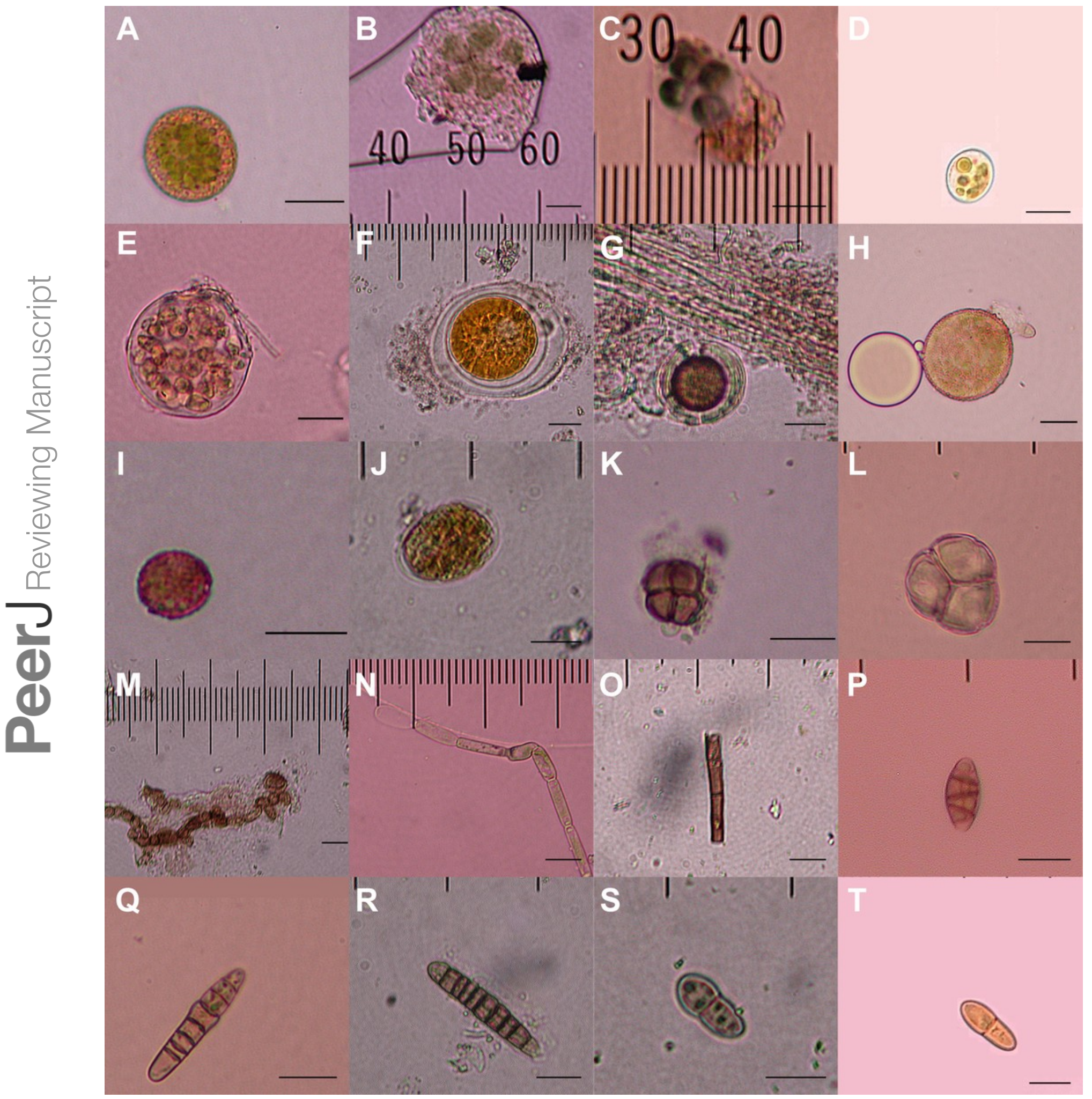

